\title{
Nutrient content and physical properties of instant baby porridge substituted with freshwater clams flour (Pilsbryoconcha exilis)
}

\author{
${ }^{1}$ Fatma, L.F., ${ }^{1}$ Afifah, D.N., ${ }^{2}$ Anantyo, D.T., ${ }^{2}$ Mulyono, ${ }^{2}$ Nugroho, T.W., ${ }^{2}$ Wahyudi, F. \\ and ${ }^{1 *}$ Nuryanto \\ ${ }^{1}$ Nutrition Science Department, Diponegoro University, Indonesia \\ ${ }^{2}$ Faculty of Medicine, Diponegoro University, Indonesia
}

\section{Article history:}

Received: 31 January 2020

Received in revised form: 26

March 2020

Accepted: 18 October 2020

Available Online: 1

November 2020

\section{Keywords:}

Instant baby porridge,

Freshwater clams,

Physical properties,

Nutrient content

DOI:

https://doi.org/10.26656/fr.2017.4(S3).S27

\begin{abstract}
Stunting is one of the nutritional problems with high frequency in Indonesia. One cause of stunted children is the improper complementary feeding practice. A good quality diet contains macronutrients (protein) and micronutrients (iron, zinc, and calcium) are linearly correlated with children's growth. A freshwater clam was a local food enriched with highprotein and zinc that is potential to be nutritional complementary foods. However, this was substituted by full cream milk in instant baby porridge. The purpose of this study was to analyze the effect of freshwater clams flour substitution on energy, protein, fat, carbohydrate, fiber, zinc, calcium, and iron as well as physical properties (bulk density, water absorption, and solubility) in instant baby porridge. The design of this study was a single factor completely randomized design with the ratio of freshwater clams flour as substituted in the instant baby porridge as $0 \%(\mathrm{~F} 0), 5 \%(\mathrm{~F} 1)$ and $10 \%(\mathrm{~F} 2)$. There was also an effect of substitution of freshwater clamss flour (Pilsbryoconcha exilis) on energy, carbohydrate, protein, fat, moisture content, ash, crude fiber, calcium, iron, and zinc $(\mathrm{p}=$ 0.0001 ) in instant baby porridge. Variation in the percentage of freshwater clamss flour substitution did not significantly influence the bulk density $(\mathrm{p}=0.085)$, solubility ( $\mathrm{p}$ $=0,05)$ and water absorption $(\mathrm{p}=0.341)$. Instant baby porridge F0 contained protein, calcium, iron, and zinc less than the requirements. Instant baby porridge $\mathrm{F} 1$ had protein and zinc less than the requirements, but calcium and iron levels met the requirements. Meanwhile, the level of protein, iron, calcium and zinc on instant baby porridge F2 met the requirements. Instant baby porridge with the substitution of freshwater clams flour increased the nutrient content which includes protein, fiber, calcium, iron, and zinc but decreased carbohydrate and fat content. Both formulations had a bulk density and solubility which meet the requirement. However, water absorption did not meet the requirements.
\end{abstract}

\section{Introduction}

One of nutritional problem which frequently occurs in Indonesia is children suffer from is malnutrition or stunting. Stunting is related to parental care especially on feeding the children during their first two years of life through breastfeeding and complementary food. Children over six months old should have received good complementary foods. However, some studies suggest that the real practice of giving complementary foods was often done in insufficient quantities and low quality compared to breast milk (World Health Organization, 2003). The good quality of diet contains macronutrients (protein) and micronutrients (iron, zinc, and calcium) which were linearly correlated with the children's growth (de Onis et al., 2006; Amare et al., 2012). A study conducted in Grobogan, Indonesia that specified in the existence of low protein and zinc intake was positively related to stunting (Shokibi and Nuryanto, 2015; Febrindari and Nuryanto, 2016). It can be concluded that stunting occurred in Grobogan, Indonesia was caused by the minimum intake of children's nutrients, especially protein, iron and zinc which was less than the minimal percentage of Nutrition Adequacy Rate (NAR).

Complementary foods should meet child's increased energy needs which are gradually adjusted to his digestive ability over the first 2 years of life (Trahms and McKean, 2008). The complementary foods 
recommended by UNICEF come from the local ingredients because they are cheap and can be easily accessed in the local area (Indonesian Ministry of Health, 2006). One type of complementary foods that have been widely made among the people was instant baby porridge. Instant baby porridge given to children is supposed to have a high bulk density, so it would not quickly make the baby feel full. According to the Ministry of Health, the manufacture of instant baby porridge is supposed to primarily meet the nutritional needs in every $100 \mathrm{~g}$. It is supposed to be completed with a 400-440 kcal of energy, 15-22 g of protein, 10-15 g of fat, $30 \mathrm{~g}$ of maximum carbohydrate, 5-8 $\mathrm{mg}$ of iron, 2.5$4 \mathrm{mg}$ of zinc and 200-400 $\mathrm{mg}$ of calcium (Indonesian Health Ministry, 2007).

Preparation of complementary feeding is generally derived from a mixture of rice flour, skim milk, refined sugar, and vegetable oil. The ingredients can be substituted with local foods rich in protein and iron to increase the nutritional content. One of the alternative local foods which is abundant and can be potentially processed into complementary foods in Grobogan is Freshwater Clams. The protein in freshwater clams was more easily absorbed by the body because it has a shorter protein fiber (Prasastyane, 2009) and consists of more variation of amino acids than vegetable protein (Muchtadi, 1989). Freshwater clams are also high in iron and zinc which are essential micronutrients for human growth, development, and maintenance of the immune system (Walker et al., 2005; King, 2011). Therefore, freshwater clams have a good prospect as alternative nutritious local complementary foods. Therefore, this study was aimed to analyze the effect of freshwater clams flour substitution on energy, protein, fat, carbohydrate, fiber, zinc, calcium, and iron as well as physical properties (bulk density, water absorption, and solubility) in instant baby porridge.

\section{Materials and methods}

\subsection{Source of material and preparation}

The main ingredients in baby porridge are rice flour, full cream milk, vegetable oil, and refined sugar. Freshwater clams were from Grobogan Regency, Central Java, Indonesia.

\subsection{Processing method}

\subsubsection{Production of freshwater clams flour}

The first step of this study was to process freshwater clams into flour by cleaning and boiling for $30 \mathrm{mins}$. Then the freshwater clams's body was sliced into thin pieces. Then it was dried using a dry oven with the temperature of $75-80^{\circ} \mathrm{C}$. Next, the dry freshwater clams was ground and sieved using 60 mesh sieves.

\subsubsection{Pregelatinizing of rice flour}

Pregelatinized manufacturing is by processing rice flour into a thick paste and then dried using a drum dryer at the temperature of $110^{\circ} \mathrm{C}$ and ground it. Then, it was sieved using a 60-mesh sieve.

\subsubsection{Preparation and production of instant baby porridge}

The initial composition of baby porridge was $35 \%$ of rice flour, $50 \%$ of full cream milk, $10 \%$ of refined sugar, $10 \%$ of vegetable oil, and $5 \%$ of refined sugar with the ratio of freshwater clams flour presented in Table 1. Each ingredient was sieved using a 60-mesh sieve and weighed according to the formulation plan. The dry ingredients that has been weighed were first mixed manually (dry mixing) and added with oil and stirred until it mixed well.

Table 1. Composition of baby porridge with three different formulations

\begin{tabular}{cccc}
\hline \multirow{2}{*}{ Material } & $\begin{array}{c}\text { Control Group } \\
(\%)\end{array}$ & \multicolumn{2}{c}{ Formulation } \\
\cline { 3 - 4 } & 0 & 5 & F2 \\
\hline Freshwater clamss flour & 50 & 50 & 10 \\
Rice flour & 35 & 30 & 25 \\
Full cream milk & 10 & 10 & 10 \\
Vegetable oil & 5 & 5 & 5 \\
Refined sugar & 100 & 100 & 100 \\
Total & & & \\
\hline
\end{tabular}

\subsection{Chemical analysis of instant baby porridge}

In this study, the data were collected from the dependent variables such as: energy, protein, fat, carbohydrate, fiber, zinc, calcium, and iron as well as physical properties (bulk density, water absorption, and solubility). The energy content was analyzed using the bomb calorimeter method. The carbohydrate content was determined by the difference, i.e. by subtracting the sum of the values of moisture, ash, protein and fat from 100 (per 100 g). Protein content was analyzed by the Bradford method. Fat content was analyzed using the soxhlet method. Fiber content was measured by the Gravimetry method. Lastly, mineral content (iron, calcium, and zinc) was analyzed using AAS (Atomic Absorption Spectrophotometer) method.

\subsection{Physical analysis of instant baby porridge}

Bulk density measurements were carried out using a measuring cup. The measured material was weighed as much as $10 \mathrm{~g}$; then put in $100 \mathrm{~mL}$ measuring cup. The bottom of the measuring cup was tapped several times until a constant volume was obtained (Okaka and Potter, 1977). The water absorption analysis procedure used a 
sample of 1 gram of flour in a tube added with $10 \mathrm{~mL}$ of distilled water. Then, it was vortexed for 2 mins and left for 15 mins. Then, it was centrifuged for 25 mins at 3000 $\mathrm{rpm}$. The supernatant was separated, then the sample was weighed. The difference between the weight of the sample after absorbing water and the dry sample per 100 $\mathrm{g}$ indicated the amount of water absorbed by the flour (Valdez-Niebla et al., 1993; Ju and Mittal, 1995), and solubility was determined using the reference from Kainuma 1967 method (Kainuma et al., 1967). The $0.5 \mathrm{~g}$ sample was heated in a $10 \mathrm{~mL}$ distilled water bath at $60^{\circ}$ $\mathrm{C}$ for 30 mins without mixing. The sample was centrifuged at $1600 \mathrm{rpm}$ for 10 mins. The supernatant was separated $(5 \mathrm{~mL})$, dried, weighed and calculated using equation.

\subsection{Statistical analysis}

The collected data were analyzed using statistical software. The effect of variations of freshwater clams flour substitution on nutrient content was tested using One-way ANOVA with a degree of assurance of $95 \%$ followed by Posthoc Tukey Test. Posthoc Tukey test was used to find out the real difference between treatments., Besides, the effect of variations of freshwater clams flour substitution on physical properties of complementary food was tested using Kruskal Wallis and continued by Mann-Whitney test.

\section{Results}

\subsection{Energy and nutrient content}

The energy and nutrients content of instant baby porridge with substitution of freshwater clams flour was presented in Table 2. Table 2 shows that there was a significant effect of freshwater clams flour substitution at the treatment level of $0 \%, 5 \%$ and $10 \%$ on the energy content $(p=0.0001)$, carbohydrates $(p=0.0001)$, protein $(\mathrm{p}=0.0001)$, fat $(\mathrm{p}=0.0001)$, fiber $(\mathrm{p}=0.0001)$, ash $(\mathrm{p}$ $=0.0001)$, water $(p=0.0001)$, calcium $(p=0.0001)$, iron $(\mathrm{p}=0.0001)$, and zinc $(\mathrm{p}=0.0001)$ in the instant baby porridge.

\subsection{Physical properties of instant baby porridge}

The physical properties of instant baby porridge with freshwater clams flour substitution is presented in Table 3. The substitution of freshwater clams flour to each treatment on the level of $0 \%, 5 \%$, and $10 \%$ did not affect the bulk density $(\mathrm{p}=0.085)$ and water absorption $(\mathrm{p}=$ $0.341)$, but affect the solubility $(\mathrm{p}=0.05)$ of instant baby porridge.

\section{Discussion}

4.1 Complementary food substituted with freshwater clams flour

\subsubsection{Energy}

Based on the analysis, the energy content of instant baby porridge substituted with freshwater clams flour ranged from 476.36 to $481.62 \mathrm{kcal} / 100 \mathrm{~g}$ and had fulfilled the requirements from The Ministry of Health. Formula F2 had the highest energy content than Formula F1 and F0 (control group). It means that the substitution of freshwater clams flour increased the energy content to $10 \%$.

\subsubsection{Carbohydrate}

Carbohydrate content was calculated by difference from the content of other nutrients such as water, ash, fiber, protein, and fat. Instant baby porridge substituted with freshwater clams flour contained carbohydrates of $60.63-65.60 \mathrm{~g} / 100 \mathrm{~g}$. There was no requirement for the carbohydrate rate in the complementary food specifications, but carbohydrate content of instant baby porridge was lower than commercial instant baby porridge (41.13 to $73.79 \mathrm{~g} / 100 \mathrm{~g}$ ) (WHO 1994). Carbohydrate content tends to decrease with the addition of freshwater clams flour. The decline was caused by the carbohydrate content of full cream milk (37.6 g/100 g) which was higher than freshwater clams flour $(3.3 \mathrm{~g} / 100$ g). Moreover, the carbohydrate content was also influenced by the percentage of protein, fiber, ash, and water. The lower the water, ash, protein and fat content, the higher the amount of carbohydrate and vice versa (Winarno, 2004).

\subsubsection{Protein}

Protein was also required to accelerate the growth of the baby which was required more per kilogram of the body weight compared to adults or older children (Trahms and McKean 2008). Amino acids from proteins were needed by the body to build bone matrix and affected bone growth through catabolism (Golden 2009). Protein levels were increased in any addition to the instant baby porridge. Dissolved protein levels of instant baby porridge substituted freshwater clams flour ranged from $8.94-13.51 \mathrm{~g} / 100 \mathrm{~g}$. The increase in protein content along with the addition of the substitution of freshwater clams flour was caused by protein content in $100 \mathrm{~g}$ of freshwater clams flour accounted for $8.1 \mathrm{~g}$ (Putri et al., 2017) with formula $F 2$ was the closest formulation to the Ministry of Health requirements (15-22 g/100 g). The protein content of freshwater clams was more easily absorbed by the body because it had a shorter protein fiber compared to beef or chicken (Pigott and Tucker, 1990) and consisted of more variations of amino acids 


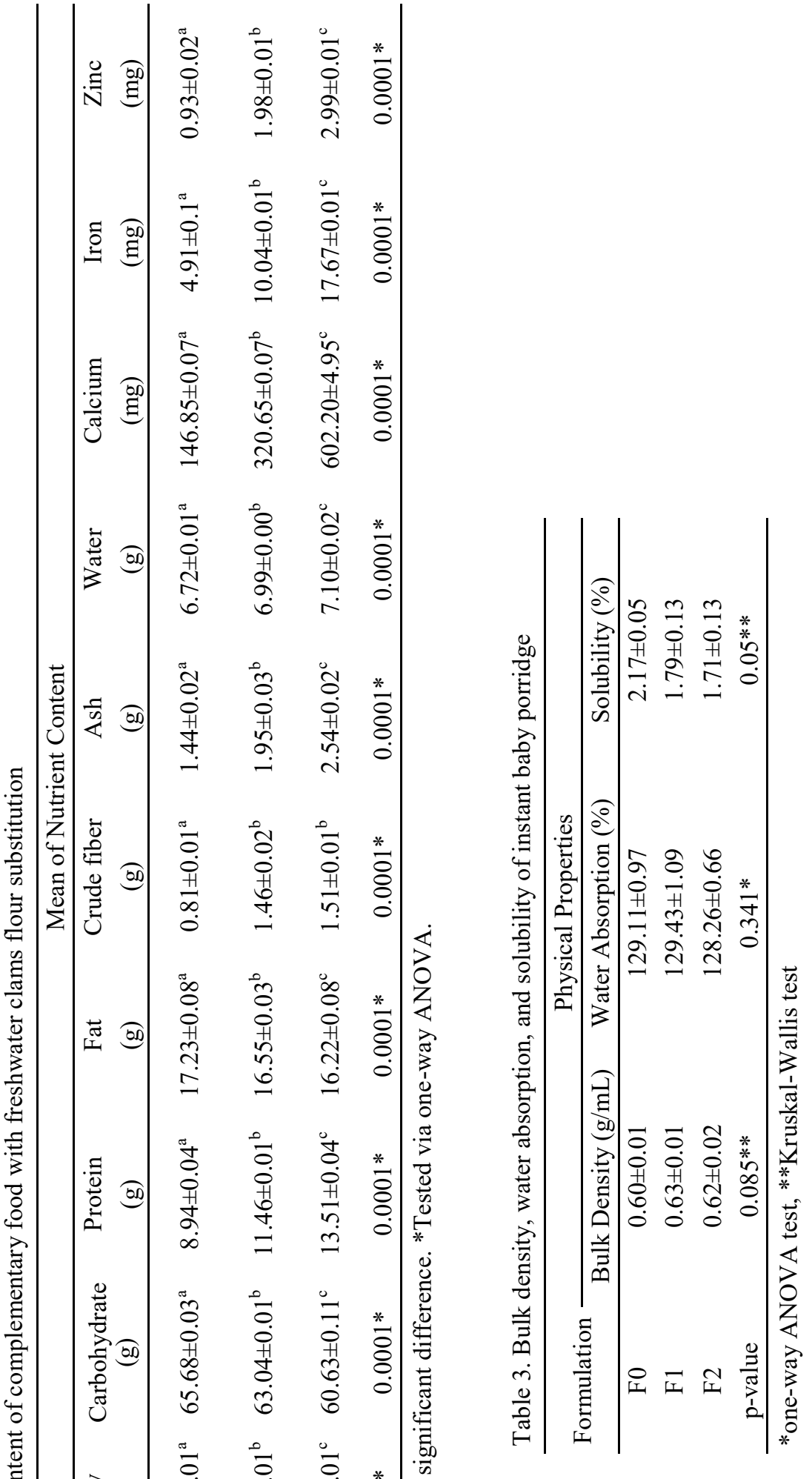


than vegetable protein (Muchtadi, 1989).

\subsubsection{Fat}

Fat is a more effective source of energy compared to carbohydrates and protein by producing calories and improving the texture and taste of food ingredients (Winarno, 2004). The results of the study showed that the proportion of children under five with a low level of fat intake was stunted more than the proportion of children under five with sufficient fat intake (Torun et al., 2006). Studies in Turkey, Ghana, and China showed that supplementation with essential fatty acids influenced the development of infant neurons and motor skills (Unay et al., 2004; Torun et al., 2006; Wang et al., 2006). The fat content of instant baby porridge produced in this study ranged from 16.22-17.23 $\mathrm{g}$ with the lowest fat content found in the F2 Formula with a $10 \%$ freshwater clams flour substitution.

The range of fat content in all formulations had met the fat content value required by The Ministry of Health $(10-15 \mathrm{~g} / 100 \mathrm{~g})$. However, the more the addition of freshwater clams flour reduced the fat content produced in instant baby porridge. This was because the fat content in freshwater clams flour (0.78 gram/100 gram) (Putri et al., 2017) was lower than full cream milk ( $28.6 \mathrm{~g} / 100 \mathrm{~g})$. Besides, the flouring process carried out on freshwater clams meat including steaming and drying contributed to the reduction of fat content (Ningsih, 2009).

\subsubsection{Crude fiber}

The crude fiber content found in baby porridge maybe insoluble dietary fiber consisting of cellulose, hemicellulose, and lignin. Fiber levels need to be a concern in food products for babies because the babies' digestive system is not yet perfect. So, it can cause diarrhea if it is found in large quantities by disrupting the digestive system and malabsorption of other nutrients in the intestine. (Bahmat et al., 2015).

The crude fiber content of instant baby porridge in this study was $0.81-1.51 \%$ with the F2 formula being the formula with the highest fiber content. This value has met the requirement from the Ministry of Health which is not more than $5 \mathrm{~g} / 100 \mathrm{~g}$. Every addition of freshwater clams flour increased the fiber content of each formulation. Increased levels of fiber occurred because the fiber contained in freshwater clams meat went through a heating process that involved browning or Maillard reaction between amino acids and products resulted from sugar degradation (Stasse-Wolthuis, 1980).

\subsubsection{Ash}

Ash content indicates the mineral content in food content. The ash content in instant baby porridge was $1.44-2.54 \%$. This value was in accordance with the maximum limit of the Indonesian National Standard which is $3.5 \mathrm{~g} / 100 \mathrm{~g}$. The ash content of instant baby porridge has increased on every addition of freshwater clams flour. This is in line with the results of the studies which showed that the higher concentration of freshwater clams meat added increased the ash content in the nuggets (Sari et al., 2018).

\subsubsection{Water}

Water content is very important in determining the durability of food ingredients because it affects physicochemical properties, microbiological and enzymatic changes (Winarno, 2002). All instant baby porridge formulations have higher water content than the requirement of the Indonesian National Standard (INS) with a maximum limit of $4 \mathrm{~g} / 100 \mathrm{~g}$.

The higher the addition of freshwater clams flour, the higher the moisture content produced by the instant baby porridge. This was presumably because the protein content of freshwater clams was associated with the high level of water in baby porridge. High protein level can increase the binding capacity of water. The higher the protein content, the higher the water content (Winarno, 2004; Damodaran and Paraf, 1997). The increase in water content was presumed to be related to the high fiber content in the freshwater clams flour, where the fiber had strong water-binding properties (Bollenback et al., 1980). Although the water content of baby porridge exceeds INS limit, food products with a water content of less than $14 \%$ were safe enough to prevent the growth of fungus and mold (Winarno, 1997).

\subsubsection{Calcium}

Calcium is one of the macro minerals that are important for the baby's growth. Calcium is also necessary for bone growth and skeletal development. Hence, the adequate calcium intake is considered as a prerequisite for normal linear growth (Institute of Medicine, 2011). Calcium level of instant baby porridge ranged from $146.85-602.20 \mathrm{mg} / 100 \mathrm{~g}$. These levels met the $200-400 \mathrm{mg} / 100 \mathrm{~g}$ required for complementary food from the Ministry of Health. F2 Formula had a higher calcium level which was $602.20 \mathrm{mg} / 100 \mathrm{~g}$ while $\mathrm{F} 0$ formulation had the lowest calcium level of 146.85 $\mathrm{mg} / 100 \mathrm{~g}$ and did not meet the requirement of the Ministry of Health. High calcium level of freshwater clams flour contributed to the calcium content in baby porridge. Previous research on freshwater clams flour showed calcium levels of $924 \mathrm{mg} / 100 \mathrm{~g}$ (Putri et al., 2017). 


\subsubsection{Iron}

Iron plays a vital role in the immune system. Deficiency of iron decreases immune function which can lead to resistance to a disease that will gradually stunt the growth of children (Bahmat et al., 2015). Iron content in the instant baby porridge substituted by freshwater clams flour ranged from 4.91-17.67 $\mathrm{mg} / 100 \mathrm{~g}$. Both formulations met the Ministry of Health requirements which ranged from 5-8 g/ $100 \mathrm{~g}$ with the highest formulation found in the substitution of freshwater clams flour by $10 \%$. Whereas the control formula or F0 approaches the minimum iron level recommended by the Ministry of Health.

Iron level of instant baby porridge was increased in each addition of freshwater clams flour. High level of iron in the freshwater clams flour contributed to the iron levels in the baby porridge. The iron content in the freshwater clams flour was included in heme iron that was easily absorbed by cells due to the low phytate content in its animal foods (Mallanes-Lopez et al., 2017).

\subsubsection{Zinc}

Zinc can affect linear growth because zinc is included in the type 2 nutrient required by toddlers aged 6-23 months. Zinc is a nutrient needed for general metabolism, so-called type 2 nutrients (King, 2011). The role of Nutrient type 2 is as a main ingredient in tissue formation (King, 2011). In this study, zinc content of instant baby porridge substituted with freshwater clams flour ranged from 0.93 to $2.99 \mathrm{mg} / 100 \mathrm{~g}$ with the highest formula found in F2 with $10 \%$ and the lowest formula found in F0/control. High level of zinc in the freshwater clams flour contributed to the zinc level in the final product of the baby porridge. The zinc level contained in $100 \mathrm{~g}$ of freshwater clams flour was high at $48.6 \mathrm{mg} / 100$ g (Putri et al., 2017).

\subsection{Physical properties of instant baby porridge}

\subsubsection{Bulk density}

The value of the density of instant baby porridge with substitution of freshwater clams flour ranged from 0.60 to $0.63 \mathrm{~g} / \mathrm{mL}$ and was not significantly different between formulations. This value was higher compared to the bulk density of commercial baby porridge (0.37$0.50 \mathrm{~g} / \mathrm{mL}$ ). This showed that with the same weight, instant baby porridge product required a small space in the baby's abdomen so that the baby would not be full quickly which allowed more nutrients to be absorbed. However, instant baby porridge was still acceptable because this value was within the normal range of bulk density by various powder foods, which was $0.30-0.80 \mathrm{~g} /$ $\mathrm{mL}$ (Wirakartakusumah et al., 1992) and considered to meet the requirements.

Complementary foods that have a low bulk density (voluminous) can cause the baby to get full quickly while the nutritional intake is not maximal. The functional capacity of the baby's stomach is only $30 \mathrm{~g} / \mathrm{kg}$ body weight so the food with high bulk density is needed; so that the baby will not be full quickly and the nutritional intake is fulfilled (Dewey and Brown, 2003).

\subsubsection{Solubility}

The solubility of instant baby porridge illustrates the texture of baby porridge after brewing with the addition of hot water. The solubility of instant baby porridge with freshwater clams flour ranged from $1.71-2.17 \%$. The addition of freshwater clams flour decreased the solubility of instant baby porridge and F2 had the lowest solubility. The lower solubility in the formulation was supposed to be caused by the low of water-soluble components such as sugar and the high water-insoluble components such as insoluble food fiber and resistant starch in the ingredients (Pangastuti et al., 2013).

\subsubsection{Water absorption}

The results of the analysis showed that the average water absorption capacity of instant baby porridge ranged from 128.26-129.43 g/g with each variation of the administration of freshwater clams flour substitution did not significantly affect water absorption. This value exceeded the water absorption capacity of commercial complementary food that was $3.60-6.20 \mathrm{~g} / \mathrm{g}$. This meant that the water absorption value of all instant baby porridge formulations in this study did not meet the requirements because the absorption capacity was higher. The value of water absorption in baby porridge had increased from the control at F1 which was 129.11 $\mathrm{g} / \mathrm{g}$ to $129.43 \mathrm{~g} / \mathrm{g}$ and decreased in F2 at $128.26 \mathrm{~g} / \mathrm{g}$. It was because the ability of water absorption in food could be reduced if the water content in the material (moisture) was too high so that it could inhibit the absorption capacity of baby porridge (Prabowo, 2010). It meant that the substitution of freshwater clams flour decreased the water absorption capacity of baby porridge by a percentage of $10 \%$.

Besides, water absorption in baby porridge is assumed to be influenced by protein components and crude fiber content. Water absorption is one of the characteristics of protein hydration, namely the ability of proteins to hold water in a food system (low water absorption). Protein will cover starch particles so water absorption becomes inhibited (Suarni et al., 2013). Crude fiber content also contributes to reducing water absorption in starch granules (Bollenback et al., 1980). 
4.3 Determination of selected complementary foods

Table 4. Proportion of nutrition composition according to the Ministry of Health Indonesia

\begin{tabular}{lcccc}
\hline \multirow{2}{*}{$\begin{array}{c}\text { Mean of Nutrient } \\
\text { Content }\end{array}$} & \multicolumn{3}{c}{ Formulation } & \begin{tabular}{c} 
Ministry of \\
Health \\
\cline { 2 - 4 } Indonesia
\end{tabular} \\
\hline Energy (kcal) & 476.36 & 474.62 & 481.62 & $400-440$ \\
Carbohydrate (g) & 65.68 & 63.04 & 60.63 & - \\
Protein (g) & 8.94 & 11.46 & 13.51 & $15-22$ \\
Fat (g) & 17.23 & 16.55 & 16.22 & $10-15$ \\
Crude fiber (g) & 0.81 & 1.46 & 1.51 & Max. 5 \\
Ash (g) & 1.44 & 1.95 & 2.54 & - \\
Water (g) & 6.72 & 6.99 & 7.1 & Max. 4 \\
Calcium (mg) & 146.85 & 320.65 & 602.2 & $200-400$ \\
Iron (mg) & 4.91 & 10.04 & 17.67 & $5-8$ \\
Zinc (mg) & 0.93 & 1.98 & 2.99 & $2.5-4.0$ \\
\hline
\end{tabular}

The selection of the best formulation was determined based on the complementary feeding requirements of the Ministry of Health and the World Health Organization (WHO) presented in Table 4.

Complementary food of instant baby porridge with substitution of freshwater clams flour has fulfilled the Ministry of Health's requirement such as: energy, fat, and fiber but the carbohydrate content did not meet the requirements but still within the range of $60 \%$ needed by babies as an energy source. Ash content in all formulations met the INS requirement. Whereas the water content in all formulations did not meet the maximum requirements of the Ministry of Health.

The complementary food of instant baby porridge F0 had protein, calcium, and zinc levels which did not meet the requirement of the Ministry of Health but the iron levels was close enough. Whereas complementary food of instant baby porridge F1 had high level of protein, water, and zinc which did not meet the requirement, but the other mineral level like calcium and iron met the requirements.

Physical properties of the instant baby porridge substituted with freshwater clams flour included bulk density and solubility have met the requirements, whereas the water absorption was higher than the commercial complementary food products. Bulk density in all formulations exceeded the bulk density of commercial instant baby porridge so that it could be deemed as having a better nutrient density. Therefore, it can be said that all formulations of instant baby porridge had the same physical properties.

Nutrition adequacy of instant baby porridge for children aged 6-11 months was presented in Table 5. Adequacy of energy from complementary food became a major factor in determining the amount of food consumed so that it affected the serving size of the products provided (Dewey and Brown, 2003). The energy needs of children aged 6-8 months can be fulfilled with $74 \mathrm{~g}$ of instant baby porridge F0, $75 \mathrm{~g}$ of instant baby porridge $\mathrm{F} 1$, and $74 \mathrm{~g}$ of instant baby porridge F2. While the energy needs in children aged 911 months can be fulfilled from all formulations instant baby porridge in $100 \mathrm{~g}$.

Formulation of instant baby porridge F2 had higher levels of protein and minerals such as calcium, iron, and zinc which have fulfilled the nutritional intake of children aged 6-11 months with a serving size of $25 \mathrm{~g}$. It was calculated based on the amount of energy consumed. Therefore, it can be concluded that the formulation of instant baby porridge F2 was the best complementary food product according to the Ministry of Health regulations, physical properties of instant products and WHO/UNICEF 1998.

\subsection{Nutrition adequacy on the serving size}

The definition of serving size in instant baby porridge substituted with freshwater clams flour in this study was based on the fulfillment of energy from the complementary food. So that by calculation, the energy was obtained by serving $25 \mathrm{~g}$ with the frequency of eating recommendation for consumption in children aged 6-8 months was 3 times, and for children 9-11 months was 4 times (Dewey and Brown, 2003).

Consumption of one serving of instant baby porridge formula F2 (5\%) in children aged 6-8 months can fulfill $33.33 \%$ energy, $32.97 \%$ protein, $33.33 \%$ calcium, $33.36 \%$ iron, and $33.21 \%$ zinc. Whereas for children aged 9-11 months can fulfill $25 \%$ of the energy needs, protein, calcium, iron, and zinc.

Table 5. Nutrition adequacy of instant baby porridge according to WHO (1998) in 6-11 months

\begin{tabular}{|c|c|c|c|c|c|c|c|c|}
\hline \multirow{2}{*}{$\begin{array}{c}\text { Mean of Nutrient } \\
\text { Content }\end{array}$} & \multicolumn{3}{|c|}{ Formulation } & \multirow{2}{*}{$\begin{array}{c}\text { 6-8 } \\
\text { months* }\end{array}$} & \multicolumn{3}{|c|}{ Formulation } & \multirow{2}{*}{$\begin{array}{c}\text { 9-11 } \\
\text { months** }\end{array}$} \\
\hline & F0 & F1 & F2 & & F0 & F1 & $\mathrm{F} 2$ & \\
\hline Energy (kcal) & $100 \%$ & $100 \%$ & $100 \%$ & 356 & $100 \%$ & $100 \%$ & $100 \%$ & 356 \\
\hline Protein (g) & $73 \%$ & $95 \% \%$ & $110 \%$ & 9.1 & $93 \%$ & $119 \%$ & $141 \%$ & 9.1 \\
\hline Calcium (mg) & $27 \%$ & $61 \%$ & $115 \%$ & 525 & $27 \%$ & $61 \%$ & $115 \%$ & 525 \\
\hline Iron (mg) & $45 \%$ & $91 \%$ & $161 \%$ & 11 & $45 \%$ & $91 \%$ & $161 \%$ & 11 \\
\hline Zinc (mg) & $33 \%$ & $70 \%$ & $107 \%$ & 2.8 & $33 \%$ & $70 \%$ & $107 \%$ & 2.8 \\
\hline
\end{tabular}

*sufficient energy from breast milk was $413 \mathrm{kcal}$; ** sufficient energy from breast milk was $379 \mathrm{kcal}$ 


\section{Conclusion}

Instant baby porridge with the substitution of freshwater clams flour increased the amount of protein, fiber, calcium, iron, and zinc but decreased carbohydrate and fat. The bulk density of instant baby porridge with the freshwater clams flour is appropriate to the bulk density range of powdered food but exceeded the normal range of bulk density of commercial porridge. The substitution of freshwater clams flour has a significant difference in solubility of each treatment given to instant baby porridge. The best formulation based on the complementary food requirements of the Ministry of Health and WHO was F2 with the best nutrient density and physical properties of instant baby porridge.

\section{Acknowledgments}

The research was funded by PNBP, Faculty of Medicine, Diponegoro University, Semarang. The author would like to deeply thank those who supported this research.

\section{References}

Amare, B., Moges, B., Fantahun, B., Tafess, K., Woldeyohannes, D., Yismaw, G., Ayane, T., Yabutani, T., Mulu, A., Ota, F. and Kassu, A. (2012). Micronutrient levels and nutritional status of school children living in Northwest Ethiopia. Nutrition Journal, 11, 1-8. https:// doi.org/10.1186/1475-2891-11-108

Bahmat, D.O., Bahar, H. and Jus'at, I. (2015). Relationship of Zinc (Zn), Vitamin A, Iron (Fe) Intake in Toddlers (24-59 Months) and Stunting in the Nusa Tenggara Islands (Basic Health Research 2010). Jakarta: UPT. Esa Unggul University Library.

Bollenback, G., Hood, L., Wardrip, F. and Edward, K. (1980). Carbohydrates and Health. Westport, Connecticut: AVI Publishing Company.

Damodaran, S. and Paraf, A. (1997). Food Protein and Their Application. New York: Marcel Dekker, Inc.

de Onis, M., Onyango, A.W., Borghi, E., Garza, C. and Yang, H. (2006). Comparison of the World Health Organization (WHO) child growth standards and the national center for health statistics/WHO International Growth Reference: implications for child health prog. Public Health Nutrition, 9(7), 942 -947. https://doi.org/10.1017/PHN20062005

Dewey, K., Brown, G. and Kenneth, H. (2003). Update on Technical Issues Concerning Complementary Feeding of Young Children in Developing Countries and Implications for Intervention Prog. Food and Nutrition Bulletin, 24, 5-28. https:// doi.org/10.1177/156482650302400102

Febrindari, A.P. and Nuryanto. (2016). Relationship of Energy Intake, Protein, Zinc, and Worm Infection in Nutritional Status of Children 12-36 Months Old. Journal of Nutrition College, 5(4), 353-359.

Golden, M.H. (2009). Proposed Recommended Nutrient Densities for Moderateraly Malnourished Children. Food and Nutrition Bulletin, 30, 267-342. https:// doi.org/10.1177/15648265090303S302

Indonesian Health Ministry. (2007). Decree of Indonesian Health Ministry Number: 224/Menkes/ SK/II/2007 Regarding Technical Specifications for Complementary Feeding. Jakarta, Indoensia: Ministry of Health.

Indonesian Ministry of Health. (2006). General Guidelines for Local Complementary Feeding 2006. Jakarta, Indoensia: Ministry of Health.

Institute of Medicine. (2011). Dietary Reference Intakes for Calcium and Vitamin D. USA: National Academies Press.

Ju, J., and Mittal, G.S. (1995). Physical properties of various starch-based fat substitutes. Journal of Food Processing and Preservation, 19(5), 361-383. https://doi.org/10.1111/j.1745-4549.1995.tb00301.x

Kainuma, K., Odat, T. and Cuzuki, S. (1967). Study of starch phosphates monoesters. Journal of Technology Society Starch, 14, 24-28.

King, J.C. (2011). Zinc: An Essential but Elusive Nutrient. The American Journal of Clinical Nutrition, 94(2), 679S-684S. https:// doi.org/10.3945/ajcn.110.005744

Mallanes-Lopez, A.M., Hernandez-Espinosa, G., Velu G., Posadas-Romano, G., Guadalupe OrdonezVillegas, V.M. and Crossa, J. (2017). Variability in iron, zinc and phytic acid content in a worldwide collection of commercial durum wheat cultivars and the effect of reduced irrigation on these traits. Food Chemistry, 237, 499-505. https://doi.org/10.1016/ j.foodchem.2017.05.110

Muchtadi, D. (1989). Evaluation of Nutritional Value of Food. Bogor: Inter-University Center for Food and Nutrition Bogor Agricultural University.

Ningsih, P. (2009). Characteristics of Proteins and Amino Acids of Freshwater Clams (Pilsbryoconcha exilis) from Situ Gede. Bogor, Indoensia: Bogor Agricultural Institute.

Okaka, J. and Potter, N. (1977). Functional and storage properties of cowpea powderwheat flour blends in breadmaking. Journal of Food Science, 42(3), 828833.

https://doi.org/10.1111/j.1365- 
Pangastuti, H.A., Affandi, D.R. and Ishartani, D. (2013). Physical and Chemical Characterization of Red Beans Flour (Phaseolus vulgaris L) with Several Preliminary Treatments. Jurnal Teknosains Pangan, 2(1), 20-29.

Pigott, G.M. and Tucker, B. (Eds.) (1990). Seafood: Effects of Technology on Nutrition. In Food Science and Technology. New York: CRC Press.

Prabowo, B. (2010). Study of Physical and Chemical Properties of Yellow Millet Flour and Red Millet Flour. Indonesia: Sebelas Maret University.

Prasastyane, A. (2009). Characteristic of Fatty Acids and Cholesterol of Freshwater Clams (Pilsbryoconcha exilis) from Situ Gede Bogor due to The Steaming Process. Indonesia: Bogor Agricultural Institute.

Putri, S.R., Anjani, G. Wijayanti, H.S. and Nuryanto. (2017). Freshwater Clams (Pilsbryoconcha exilis) as a Potential Local Mineral Sources in Weaning Food to Overcome Stunting in Grobogan, Central Java, Indonesia. IOP Conference Series: Earth and Environmental Science, 116, 1-14. https:// doi.org/10.1088/1755-1315/116/1/012077

Sari, I.P., Herpandi. and Lestari, S.D. (2018). The Physicochemical and Sensory Characteristics of Freshwater Clams Nuggets (Pilsbryoconcha exilis). Jurnal Teknologi Hasil Perikanan, 7, 76-85. https:// doi.org/10.36706/fishtech.v7i1.5983

Shokibi, A. and Nuryanto. (2015). The Relationship of Energy, Protein, Zinc Intake, and Physical Fitness to Stunting Children Learning Achievement in Penganten I, II, and III Elementary Schools in Klambu District, Grobogan Regency. Journal of Nutrition College, 4(1), 71-78. https:// doi.org/10.14710/jnc.v4i1.8623

Stasse-Wolthuis, M. (1980). Influence of Dietary Fiber on Cholesterol Metabolism and Colonic Function in Healthy Subjects. World Review of Nutrition and Dietetics, 36, 100-140. https:// doi.org/10.1159/000393155

Suarni, I.U., Aqil and Firmansyah, I.U. (2013). Diversity of Starch Quality of Several Corn Varieties. Penelitian Pertanian Tanaman Pangan, 32(1), 5056.

Torun, B., Davis, P.S.W., Livingstone, M.B.E., Paolisso, M., Sackett, R. and Spurr, G.B. (2006). Energy Requirement and Dietary Energy Recommendations for Children and Adolescents 1-18 years old. European Journal of Clinical Nutrition, 8(7a), 968993. https://doi.org/10.1079/PHN2005791

Trahms, C. and McKean, K.N. (2008). Nutrition during infancy. In Mahan, L.K. and Escott-Stump, S. (Eds.) Krause's Food and Nutrition Therapy. Canada:

\section{Elsevier.}

Unay, B. Sarici, S.U., Ulas, U.H., Alpay, F. and Gokcay, E. (2004). Nutritional Effects on Auditory Brainstem Maturation in healthy term infants. Arch Dis Child Fetal Neonatal, 89(2), F177-F179. https:// doi.org/10.1136/adc.2002.021014

Valdez-Niebla, J.A., Paredes-Lopez, O., Vargas-Lopez, J.M. and Hernandez-Lopez, D. (1993). Moisture Sorption Isotherms and Other Physicochemical Properties of Nixtamalized Amaranth Flour. Food Chemistry, 46(1), 19-23. https:// doi.org/10.1016/0308-8146(93)90069-R

Walker, C.F., Kordas, K., Stoltzfus, R.J. and Black, R.E. (2005). Interactive Effects of Iron and Zinc on Biochemical and Functional Outcomes in Supplementation Trials. The American Journal of Clinical Nutrition, 82(1), 5-12. https:// doi.org/10.1093/ajcn/82.1.5

Wang, Y., Wang, F., Wang, K. and Chen, C. (2006). Effects of Nutrient Fortified Complementary Food Supplements on Development of Infants and Young Children in Poor Rural Area of Gansu Province. Journal of Hygiene Research, 35(6), 772-774.

WHO. (1994). Codex Alimentarius Standards for Foods for Special Dietary Uses (including foods for infants and children), Vol.4. Joint FAO/WHO Food Standards Program Rome: WHO, Codex Alimentarius Commission.

Winarno, F. (1997). Food Chemistry and Nutrition, Jakarta: Gramedia Pustaka Utama.

Winarno, F. (2002). Food Chemistry and Nutrition, Jakarta: Gramedia Pustaka Utama.

Winarno, F. (2004). Food Chemistry and Nutrition, Jakarta: Gramedia Pustaka Utama.

Wirakartakusumah, M.A., Abdullah, K. and Am, S. (1992). Physical Properties of Food. Bogor: PAU Food Nutrition, Bogor Agricultural University.

World Health Organization. (2003). Complementary Feeding: Report of the Global Consultation, and Summary of Guiding Principles for Complementary Feeding of the breastfed child. Geneva: WHO. 